\title{
Shareholder Wealth Effects of the Private Securities Litigation Reform Act of 1995
}

\author{
MARILYN F. JOHNSON \\ The Eli Broad College of Business, East Lansing, MI 48824 \\ RON KASZNIK \\ Graduate School of Business, Stanford University, Stanford, CA 94305 \\ KAREN K. NELSON \\ Graduate School of Business, Stanford University, Stanford, CA 94305
}

johnsonm@umich.edu

kasznik_ron@gsb.stanford.edu

knelson@gsb.stanford.edu

\begin{abstract}
This paper investigates the reaction of stock prices to enactment of the Private Securities Litigation Reform Act of 1995 (PSLRA). Based on a sample of 489 high-technology firms, we find that the PSLRA was wealth-increasing, on average, and that the market reaction is more positive for firms at greatest risk of being sued in a securities class action. However, we also show that the PSLRA was less beneficial for firms likely to be the subject of a meritorious lawsuit. Collectively, our evidence implies that shareholders generally benefit from restrictions on private securities litigation, although these benefits are mitigated when other mechanisms for curbing fraudulent activity are inadequate.
\end{abstract}

Keywords: Securities litigation, litigation risk, regulatory event study

In December 1995, Congress enacted the Private Securities Litigation Reform Act of 1995 (PSLRA), concluding a long, and often controversial, legislative effort to reform federal securities laws. Considered by some to be the most significant securities legislation in several decades, the PSLRA contains a wide variety of measures intended to protect publicly traded firms, their auditors, and other professional advisers from abusive class action litigation. The PSLRA also imposes new requirements regarding auditors' responsibility to detect and disclose fraud. Proponents of the PSLRA argued that it would benefit investors by curtailing frivolous shareholder lawsuits that require substantial corporate resources to defend or settle. Opponents countered that it would increase the incidence of fraud by effectively preventing meritorious claims from being heard in federal courts. ${ }^{1}$

The purpose of this study is to measure the effect of the PSLRA on firm value by investigating the reaction of common equity prices to its passage. Because key events late in the legislative process (i.e., a Presidential veto and subsequent Congressional override) were unexpected, our examination provides a relatively powerful test of the PSLRA's economic consequences. This study is important given recent calls by the Securities and Exchange Commission (SEC) and others for measures that provide shareholders with greater protection from financial reporting failures (e.g., AICPA, 1992, 1994; National Association of Corporate Directors, 1992; Levitt, 1998). The PSLRA's impact on shareholder wealth 
is relevant to these discussions because it indicates a change in the perceived cost of an alternative disciplining mechanism, the system of private securities litigation.

Our analysis focuses on a sample of 489 firms from three industries-pharmaceuticals, computer hardware, and computer software-that are frequently the target of class action securities litigation. We draw three primary conclusions from our empirical results. First, the PSLRA was wealth-increasing, on average, for shareholders of high-technology firms. Abnormal returns associated with the veto are significantly negative, while those associated with both the House and Senate override votes are significantly positive. Second, the market reaction is more positive for firms at relatively greater risk of litigation. We estimate the firm-specific probability of litigation using a broad set of market-based and financial reporting variables as predictors of lawsuit filings.

Third, although the market response to the PSLRA is increasing in firms' overall risk of litigation, it is decreasing in the incremental probability of being sued for committing fraud. Although restricting frivolous private securities litigation is good news for shareholders, the PSLRA also makes it more difficult to pursue meritorious claims (Avery, 1996). This is bad news for investors seeking redress for legitimate losses due to fraudulent activity. The aggregate impact of the PSLRA reflects the netting of these effects. Taken together, our evidence suggests that although the benefits of the PSLRA dominate, the market perceived its passage to be less advantageous for shareholders of firms with a high risk of being sued for committing fraud.

This study is related to Spiess and Tkac (1997) who find an overall positive reaction to enactment of the PSLRA, but no evidence linking that reaction to the perceived costs and benefits of litigation reform. In contrast to their analysis, which is based on three corporate governance variables that proxy for a firm's susceptibility to a meritorious class action suit, we document significant evidence that the market reaction is increasing in our more comprehensive measure of firms' overall litigation risk. However, the positive effect diminishes as the probability of being sued for committing fraud increases. Our findings suggest that investors benefit less from restrictions on private securities litigation when other mechanisms for curbing fraud are inadequate.

This study is also related to recent research that examines the PSLRA's impact on litigation activity (Grundfest and Perino, 1997) and the voluntary disclosure of forward-looking information (Johnson, Kasznik, and Nelson, 2000). Our research approach complements these studies because it allows us to assess the aggregate effect of the PSLRA's many provisions, and to quantify that effect in terms of its impact on shareholder wealth. Our findings are also of interest in relation to research that documents a positive association between aggressive financial reporting and auditor litigation (e.g., Lys and Watts, 1994; Bonner, Palmrose, and Young, 1998). We report analogous results for securities litigation against public companies, and also document that the PSLRA was less beneficial for shareholders of firms likely to be sued for financial statement fraud.

More generally, this study contributes to our understanding of the determinants of firms' litigation risk. A better understanding of these factors is important not only for firms' managers and directors, but also for their auditors. Prior research (e.g., Francis, Philbrick, and Schipper, 1994; Jones and Weingram, 1996; Skinner, 1996) focuses on a relatively limited set of market-based explanatory variables that characterize frivolous "strike" suits. 
In contrast, our analysis includes a broad set of merit and non-merit based variables, thus allowing for a more complete assessment of firms' overall litigation risk, as well as the risk of a meritorious versus frivolous lawsuit. Our model explains 41 percent of the variation in lawsuit filings within a sector known for its high rate of litigation.

The remainder of the paper proceeds as follows. Section 1 discusses key provisions of the PSLRA and its potential impact on stock prices. Section 2 identifies important events in the PSLRA's legislative history. Section 3 describes the sample and examines the mean price reaction to enactment of the PSLRA. Section 4 provides evidence on the association between the market reaction and firms' litigation risk. Section 5 concludes the paper.

\section{The Private Securities Litigation Reform Act of $\mathbf{1 9 9 5}$}

\subsection{Key Provisions}

Congress enacted the PSLRA in response to claims of widespread abuse in the system of private securities litigation (Conference Report, 1995; Avery, 1996). For example, proponents of reform, primarily high-technology industries and the accounting profession, alleged during congressional hearings that federal securities laws promoted the routine filing of "strike" suits based solely on a large decline in stock price. These suits often targeted defendants with "deep pockets" regardless of their culpability, and tended to coerce settlements from defendants who were unwilling or unable to incur the high costs of protracted discovery and litigation. Moreover, lawyers frequently used "professional plaintiffs" who received bounty payments for filing class action lawsuits against companies in which they had only a nominal interest. There was also concern that abusive litigation was severely limiting managers' communication of forward-looking information to the marketplace.

The PSLRA contains a diverse assortment of provisions designed to address these concerns. Specifically, it establishes a statutory safe harbor protecting firms from liability for voluntary disclosures of financial projections and other forward-looking information (see Johnson, Kasznik, and Nelson (2000) for additional discussion). In addition, the PSLRA institutes a heightened pleading standard that makes it more difficult for plaintiffs to allege securities fraud without specific evidence of wrong-doing. To prevent plaintiffs from conducting a "fishing expedition" for evidence to support their claims, the PSLRA also provides for a stay of discovery while a motion to dismiss is pending. Furthermore, the first party to file a claim must notify prospective class members of the action, with the court determining the lead plaintiff from among this group. These provisions are aimed at giving the plaintiffs with the largest financial interest in the case (typically institutional investors) the right to control the course of the litigation and to select lead counsel. The PSLRA also limits attorney's fees to a "reasonable percentage" of any damage award, and imposes monetary sanctions on those who file frivolous lawsuits.

Other provisions of the PSLRA primarily affect firms' professional advisors, including outside directors and auditors. Most importantly, the PSLRA establishes a system of proportionate, as opposed to joint and several, liability for defendants who do not knowingly commit securities fraud. In addition, the PSLRA specifies procedures to be followed by auditors in connection with the discovery of illegal activities. 


\subsection{Potential Impact on Shareholder Wealth}

There has been considerable disagreement about the economic implications of the PSLRA, primarily because many of its provisions significantly alter the treatment of meritorious as well as frivolous claims. The SEC has consistently stressed that it considers private actions to be a "necessary supplement" to its own efforts in policing fraud, and the primary vehicle for compensating defrauded investors. ${ }^{2}$ However, prior to the PSLRA there was a widespread perception that the securities litigation system did not effectively screen out cases that lacked merit. ${ }^{3}$ With the enactment of the PSLRA, Congress sought to restore the balance between protecting investors from fraud and deterring frivolous lawsuits.

There are two competing hypotheses regarding the effect of the PSLRA on shareholder wealth. The first suggests that investors will benefit, on average, from the PSLRA's restrictions on private securities litigation because many lawsuits are of questionable merit, and the cost to firms of contesting or settling such suits greatly exceeds any harm suffered by investors. Supporting this argument are legal theories suggesting that plaintiffs' attorneys have incentives to pursue actions that are not optimal from the standpoint of the plaintiffs (Coffee, 1985), and that claims in shareholder class action suits exceed the net harm to society (Easterbrook and Fischel, 1985). Moreover, the outcome of shareholder litigation is typically a settlement that is independent of the merits of the case (Alexander, 1991). There is also evidence that plaintiffs' lawyers follow fairly simplistic decision rules in deciding when to file lawsuits in that stock market variables have relatively high explanatory power in discriminating between firms that get sued and those that do not (e.g., Jones and Weingram, 1996; Skinner, 1996). In addition to reducing the costs imposed by litigation, the PSLRA may encourage firms to adopt a more forthcoming disclosure policy, yielding potential economic benefits such as a lower cost of capital (Botosan, 1997), and greater investor interest (Lang and Lundholm, 1996).

The competing hypothesis suggests that the restrictions imposed by the PSLRA will be value-decreasing, on average, because it will be more costly to pursue legitimate claims. Moreover, managers will view the less threatening legal environment as an opportunity to engage in fraudulent activity at the expense of shareholders. Left unchecked, securities fraud could have a number of negative effects on shareholder wealth. For example, misrepresentations regarding company operations, financial performance, or future prospects could impair the ability of shareholders to monitor the performance of the firm and its managers. In addition, company insiders could profit from their knowledge of the fraudulent activity by selling to uninformed investors at inflated prices (e.g., Summers and Sweeney, 1998; Beneish, 1999). The increased information asymmetry could also result in decreased liquidity, and thus a higher cost of capital (e.g., Amihud and Mendelson, 1986).

The conflicting nature of these arguments prevents us from offering a directional prediction regarding the market reaction to enactment of the PSLRA. ${ }^{4}$ The average share price effect depends on the relative importance to shareholders of a reduction in the cost of frivolous litigation compared to an increase in the potential for fraudulent activity. If the cost to firms of defending and settling lawsuits is greater (less) than the benefits derived from the suits' disciplining effects, on average, the market will react positively (negatively) to events that 
increased the likelihood of passage, i.e., the House and Senate override votes, and negatively (positively) to events that decreased the likelihood of passage, i.e., the Presidential veto. ${ }^{5}$

We also investigate whether the magnitude of the market reaction is associated with the risk of being sued in a securities class action. The direction of this association, however, depends on whether the primary determinant of the cross-sectional variation in litigation risk is due to frivolous or meritorious claims. If most of the variation is explained by frivolous litigation, then the market reaction will be increasing in firms' overall litigation risk. Conversely, if most of the variation is explained by meritorious claims, then the market reaction will be decreasing. To provide further evidence on the association between litigation risk and the market reaction, we disaggregate firms' overall litigation risk into components that indicate the incremental probability that the firm will be sued for committing fraud and the probability that it will be sued for other, non-merit based factors. We expect the market reaction to be decreasing in the first component and increasing in the second component. Evidence consistent with these cross-sectional predictions provides a more direct indication that the observed market reaction is attributable to litigation reform rather than some confounding event. ${ }^{6}$ In addition, separately quantifying the benefits and costs implicit in the overall market reaction allows for a more complete assessment of the PSLRA's economic consequences.

\section{Legislative History}

A major obstacle to measuring the impact of new legislation on shareholder wealth is the difficulty of identifying precisely the dates on which information becomes available to market participants (Campbell, Lo, and MacKinley, 1997). Debates and hearings typically occur over an extended period of time, with any accompanying wealth effects gradually incorporated into stock prices. For the PSLRA, passage appeared to be anticipated shortly after it was introduced by House Republicans on January 4, 1995. For example, The Wall Street Journal (WSJ) suggested that it was "virtually certain" that Congress would "push through legislation restricting investor lawsuits against publicly traded companies" (WSJ, 1995a). Both Republicans and Democrats supported litigation reform, although the Democrats generally believed that the strict measures proposed by the Republicans would restrict investors' ability to pursue legitimate claims (Avery, 1996). However, despite the initial predictions, unexpected events late in the legislative process raised serious questions about the PSLRA's ultimate fate.

After receiving Congressional approval, the PSLRA was sent to President Clinton on Wednesday, December 6, 1995. Under the Constitution, the President has ten calendar days to sign or veto a bill before it automatically becomes law. Clinton initially indicated that he would sign the PSLRA (WSJ, 1995b). However, on Monday, December 18, 1995, the day before the decision deadline, "speculation was rampant on Capitol Hill" that the president had decided to veto the legislation (National Journal's Congress Daily, 1995). ${ }^{7}$ Congressional sources attributed Clinton's about-face to his dinner the previous Friday evening with well-known strike suit lawyer William Lerach, a vocal opponent of the PSLRA and major contributor to the Democratic party. The prospect of a presidential veto was a serious threat to the PSLRA because Congress had never overridden a Clinton veto at that 
point in time, and furthermore, the Senate was one vote short of the required two-thirds margin. ${ }^{8}$

President Clinton vetoed the PSLRA on December 19, 1995, less than one hour before the midnight deadline. In his veto message, he expressed support for legislation reforming federal securities laws, but objected to three elements of the PSLRA that would, in his view, "have the effect of closing the courthouse door on investors who have legitimate claims." First, he stated that in going beyond the already high pleading standard of the Second Circuit, the PSLRA created an unacceptable procedural hurdle. Second, he maintained that the language in the Statement of Managers, which would be used by the courts as a guide to congressional intent, weakened the safe harbor cautionary language required by the PSLRA. Finally, he argued that the sanction provisions treated plaintiffs more harshly than defendants in a manner that was too close to a "loser pays" standard. Undeterred by the President's objections, the House voted early the next day, December 20, 1995, to override the veto. Although there was speculation that the PSLRA's opponents would be able to sway enough votes in the Senate to sustain the veto (WSJ (1995c)), on December 22, 1995 the Senate voted 68-30 to enact the legislation.

We focus our analysis on the veto and subsequent congressional override as key events that were sufficiently unexpected as to cause a substantial revision in the probability that the PSLRA would become law. ${ }^{9}$ Because the veto occurred after the market closed on December 19, 1995, and the House override occurred shortly after noon the next day, we are not able to examine the market reaction to the actual veto using daily stock return data. However, press reports indicated that there was widespread speculation on December 18, 1995 that the bill would be vetoed. Thus, we examine December 18, 1995 for evidence of a market reaction to the veto, and December 20, 1995 and December 22, 1995 for evidence of a market reaction to the House and Senate override, respectively. ${ }^{10}$

\section{The Mean Stock Price Reaction}

We focus our investigation on firms that have been particularly vulnerable to class action securities litigation, and thus were most likely to be affected by reform of the litigation system. Specifically, our sample consists of firms in the pharmaceutical (SIC codes 2833-2836), computer hardware (SIC codes 3570-3577), and computer software (SIC codes 7371-7379) industries because prior research suggests that firms in high-technology industries are sued more often than other firms (e.g., Francis, Philbrick, and Schipper, 1994; Kasznik and Lev, 1995). Our initial sample consists of 547 U.S. public companies from these industries that have complete 1995 CRSP daily returns data, and are listed on Compustat. To estimate litigation risk, which we discuss in more detail in the next section, we also require a complete series of 1994 CRSP daily returns, a 1995 proxy statement with the necessary corporate governance disclosures, and data on insider trading activity. These additional data requirements reduce the size of the final sample to 489 firms, distributed fairly evenly among the three industries (191 pharmaceutical, 128 hardware, and 170 software).

We analyze the mean stock market reaction to the events identified above using the multiple regression model proposed by Schipper and Thompson (1983). A separate portfolio is formed for the full sample and each of the three industry subsamples, and the following 
model is estimated for each portfolio:

$$
\tilde{R}_{p t}=\alpha_{p}+\beta_{p} \tilde{R}_{m t}+\sum_{k}^{3} \gamma_{p k} D_{k t}+\tilde{e}_{p t} .
$$

$\tilde{R}_{p t}$ is the return on portfolio $p$ on each of the 251 trading days in calendar year 1995 , weighted using the diagonal elements of the covariance matrix of residuals to mitigate cross-sectional heteroscedasticity. $\tilde{R}_{m t}$ is the return on the CRSP equal-weighted index on day $t$, although untabulated results indicate that inferences are similar using the valueweighted market return. Finally, $D_{k t}$ is an indicator variable equal to one on each of the three event dates - veto, House override, and Senate override - and zero otherwise. The coefficient estimates on the event date indicator variables indicate the mean abnormal return associated with each event. To assess the overall significance of the PSLRA's enactment, we also compute the cumulative impact of the veto-override. ${ }^{11}$

Table 1 reports regression summary statistics from the estimation of equation (1). The full sample results indicate a significant negative abnormal return of $1.50 \%$ in response to the veto, followed by significant positive abnormal returns of $1.45 \%$ and $1.33 \%$ in response to the House and Senate override, respectively. Because the original Senate approval was one vote short of the two-thirds super-majority needed to sustain an override, the positive abnormal return associated with the Senate override likely suggests that the House vote did not resolve all remaining uncertainty about the PSLRA's fate. The last row indicates that the cumulative reaction to the veto-override is positive and significant, consistent with the hypothesis that the PSLRA was wealth-increasing, on average, for investors who held stock in high-technology firms at the time of its passage. We find similar results in all three industry subsamples reported in the remaining columns of Table 1 .

\section{The Association Between the Market Reaction and Firms' Litigation Risk}

In this section we investigate whether the market reaction to enactment of the PSLRA varies cross-sectionally with firms' ex ante risk of litigation. Section 4.1 describes how we construct our litigation risk proxy, while Section 4.2 presents the results of our empirical tests.

\subsection{Estimation of Litigation Risk}

Prior research focuses on stock market variables as predictors of securities class actions. The evidence indicates that market capitalization $(M V E)$, equity beta (Beta), and share turnover (Turnover) are positively associated with the probability of being sued, while prior year cumulative returns (Cum. Return), large, sudden stock price declines (Min. Return), and return skewness (Skewness) are negatively associated with the probability of being sued (Francis, Philbrick, and Schipper, 1994; Jones and Weingram, 1996; Skinner, 1996). These variables, whose measurement is described in more detail below, capture many of the characteristics claimed to be indicative of frivolous "strike" suits. However, they may also 
Table 1. Abnormal returns to key event dates relating to the Private Securities Litigation Reform Act of 1995.

\begin{tabular}{|c|c|c|c|c|c|c|c|c|c|}
\hline \multirow[b]{2}{*}{ Date } & \multirow[b]{2}{*}{ Event } & \multicolumn{2}{|c|}{$\begin{array}{l}\text { Full Sample } \\
(\mathrm{N}=489)\end{array}$} & \multicolumn{2}{|c|}{$\begin{array}{c}\text { Pharmaceuticals } \\
\qquad(\mathrm{N}=191)\end{array}$} & \multicolumn{2}{|c|}{$\begin{array}{l}\text { Hardware } \\
(\mathrm{N}=128)\end{array}$} & \multicolumn{2}{|c|}{$\begin{array}{l}\text { Software } \\
(\mathrm{N}=170)\end{array}$} \\
\hline & & $A R$ & $p$-value ${ }^{\mathrm{a}}$ & $A R$ & $p$-value ${ }^{a}$ & $A R$ & $p$-value ${ }^{\mathrm{a}}$ & $A R$ & $p$-value ${ }^{\mathrm{a}}$ \\
\hline $12 / 18 / 95$ & Veto & -1.50 & 0.01 & -1.16 & 0.09 & -1.23 & 0.09 & -2.08 & 0.00 \\
\hline \multirow[t]{2}{*}{$12 / 20 / 95$} & House & & & & & & & & \\
\hline & Override & 1.45 & 0.01 & 1.73 & 0.01 & 1.63 & 0.02 & 1.00 & 0.14 \\
\hline \multirow[t]{3}{*}{$12 / 22 / 95$} & Senate & & & & & & & & \\
\hline & Override & 1.33 & 0.01 & 2.82 & 0.00 & 0.98 & 0.16 & -0.08 & 0.90 \\
\hline & Cumulative & 4.28 & 0.00 & 5.71 & 0.00 & 3.85 & 0.00 & 2.99 & 0.01 \\
\hline
\end{tabular}

$A R$ is the coefficient $\left(\gamma_{p k}\right)$ of event dummy variables from the following model:

$\tilde{R}_{p t}=\alpha_{p}+\beta_{p} \tilde{R}_{m t}+\sum_{k}^{3} \gamma_{p k} D_{k t}+\tilde{e}_{p t}$

where:

$\tilde{R}_{p t}=$ return on portfolio $p$ on each of the 251 trading days in calendar year 1995 , weighted using the diagonal elements of the covariance matrix of residuals to mitigate cross-sectional heteroscedasticity,

$\tilde{R}_{m t}=$ equal-weighted market return on day $t$, and

$D_{k t}=$ one for the $k$ th event, and zero otherwise.

Portfolio $p$ is either the full sample, or one of three industry samples defined by the following SIC codes: Pharmaceuticals (2833-2836), Hardware (3570-3577) and Software (7371-7379).

a Reported $p$-values indicate the two-tailed significance levels of the $t$-statistic (F-statistic) for the individual (cumulative) reaction.

be correlated with other firm characteristics that are plausibly associated with the merits of shareholders' claims, such as managers' incentives to adopt overly aggressive accounting techniques and insider trading.

Although prior literature has not directly examined the association between securities litigation and firms' accounting practices, we speculate that the likelihood of shareholder litigation is increasing in management's propensity to engage in aggressive financial reporting. In particular, aggressive reporting may not only serve as the basis for a shareholder suit, but also may increase the likelihood that shareholders will suspect managerial misconduct when they observe a substantial stock price decline. Dechow, Sloan, and Sweeney (1996) identify four characteristics that are associated with aggressive financial reporting behavior on the part of firms subject to SEC accounting enforcement actions alleging a violation of Generally Accepted Accounting Principles: (1) CEO Power (a proxy for the CEO's influence over the Board of Directors), (2) Monitoring (a proxy for low oversight of management), (3) Financing, (a proxy for the demand for external financing), and (4) Leverage, (a proxy for firms' closeness to debt covenant violations). ${ }^{12}$ CEO Power and Monitoring capture characteristics of corporate governance structures that facilitate aggressive financial reporting, while Financing and Leverage indicate two important motives for such behavior. Because aggressive reporting is more likely to occur when firms have both the incentive and the opportunity to manipulate earnings (e.g., Dechow, Sloan, and Sweeney, 1996), we also consider the interactions between these two sets of variables in our analysis of litigation risk. Our final proxy for the merit of shareholders' claims captures the amount of trading activity by corporate insiders (Insider Sales) because plaintiffs' lawyers 
frequently allege insider trading as a basis for legal liability (e.g., Grundfest and Perino, 1997).

We estimate the risk of litigation for each firm in our sample using a probit model that explains lawsuit filings (Litigation) as a function of all of the variables described above:

$$
\begin{aligned}
\operatorname{Prob}_{\left(\text {Litigation }_{i}=\right.} & 1)=F\left(\alpha+\beta_{1} \text { MVE }_{i}+\beta_{2} \text { Beta }_{i}+\beta_{3} \text { Cum. }_{\text {Return }}\right. \\
& +\beta_{4}{\text { Min. } \text { Return }_{i}+\beta_{5} \text { Skewness }_{i}+\beta_{6} \text { Turnover }_{i}} \\
& +\beta_{7} \text { CEOPower }_{i}+\beta_{8} \text { Monitoring }_{i}+\beta_{9} \text { Financing }_{i} \\
& +\beta_{10} \text { Leverage }_{i}+\beta_{11} \text { CEOPower }_{i} \times \text { Financing }_{i} \\
& +\beta_{12} \text { CEOPower }_{i} \times \text { Leverage }_{i}+\beta_{13} \text { Monitoring }_{i} \times \text { Financing }_{i} \\
& \left.+\beta_{14} \text { Monitorin }_{i} \times \text { Leverage }_{i}+\beta_{15} \text { InsiderSales }_{i}+v_{i}\right),
\end{aligned}
$$

where:

$$
\begin{aligned}
\text { Litigation }= & \text { one if the Securities Class Action Alert indicated that the firm was } \\
& \text { a defendant in a securities class action lawsuit in either } 1994 \text { or } \\
& \text { 1995, zero otherwise, } \\
\text { MVE = } & \text { market value of common equity at the end of the } 1994 \text { (billions), } \\
\text { Beta = } & \begin{array}{l}
\text { slope coefficient from a regression of daily returns for the first } \\
\text { eleven months of } 1995 \text { on the equal-weighted market index, }
\end{array}
\end{aligned}
$$

Cum. Return $=$ cumulative daily return for the first eleven months of 1995 ,

Min. Return $=$ minimum return over any contiguous 20-day trading period during 1994 or the first eleven months of 1995 ,

Skewness $=$ skewness of raw returns, measured using daily returns for the first eleven months of 1995 ,

Turnover $=1-(1-\text { Turn })^{231}$, where Turn is average daily trading volume divided by the number of shares outstanding, and 231 is the number of trading days in the first eleven months of 1995 ,

CEO Power $=$ a factor measuring the CEO's influence over the Board of Directors,

Monitoring $=$ a factor measuring low oversight of management,

Financing $=$ one if the firm issued debt or equity in 1994 or 1995, zero otherwise,

Leverage $=$ ratio of debt to equity at the end of 1994 , and

Insider Sales = mean annual net insider sales over the period 1993-95 (millions).

Table 2 presents descriptive statistics for the variables in our model. Consistent with claims that high-technology firms are sued frequently, 27 percent of our sample were involved in a lawsuit in the two years immediately preceding enactment of the PSLRA. The 
market variables are also representative of firms in this sector. For example, there is extreme variation in firm size, indicated by a mean $M V E$ ( $\$ 1.71$ billion) that is more than ten times the median (\$120 million). The mean (median) Beta of 1.24 (1.21) and Min. Return of -28 (-26) percent reflect the volatility of technology stocks. Long-run market performance, indicated by a mean (median) Cum. Return of 61 (53) percent, was quite strong. Descriptive statistics for the remaining litigation risk proxies reveal substantial cross-sectional variation in board composition, ownership structure, and financing. In addition, the level of insider trading activity is relatively high compared to prior research (e.g., Summers and Sweeney, 1998), consistent with the prevalence of option-based compensation in the technology sector.

Table 3 reports summary statistics for the probit regression. Consistent with prior research, we find that the incidence of litigation is significantly associated with several of the market variables. Specifically, firms that are large and actively traded, as well as those with low prior year returns and large stock price drops, are significantly more likely to be sued than other firms. In addition, several of the variables that indicate fraud are statistically significant incremental to the market variables. The results indicate that independently CEO Power, Financing, and Insider Sales have explanatory power, while Leverage is significant when interacted with the governance proxies. ${ }^{13}$ Together, these variables explain 41 percent of the variation in lawsuit filings within three industries known for their high rate of litigation. Untabulated summary statistics reveal considerable cross-sectional variation in the estimated probability of litigation obtained from this analysis. Specifically, the estimated probabilities range from 0.01 to 0.99 , with a mean (median) of $0.20(0.08)$. We interpret these estimated probabilities as a proxy for firms' litigation risk.

\subsection{Effect of Litigation Risk on the Market Reaction}

We investigate whether the stock price reaction varies cross-sectionally with firms' litigation risk using the weighted portfolio approach developed by Sefcik and Thompson (1986), where the portfolio weight is based on the firm-specific probability of litigation estimated in the previous section. ${ }^{14}$ The results reported in Table 4 indicate that the market reaction is increasing in firms' overall risk of litigation. Specifically, there is a significant negative reaction to the veto, and a significant positive reaction to the House and Senate overrides. Moreover, the cumulative veto-override abnormal return is positive and significant at the 0.00 level. These findings are consistent with claims that most of the cross-sectional variation in litigation risk is related to non-merit based factors.

Although the results presented thus far suggest that the positive effects of the PSLRA dominate, it is possible that the PSLRA was relatively less beneficial for shareholders of firms with a greater potential for committing fraud. To determine whether there is a differential market reaction for these firms, we compare the abnormal returns associated with the incremental probability that firms will be sued for committing fraud to the abnormal returns associated with the probability that firms will be sued for other factors. We measure the incremental probability of being sued for fraud as the total probability of litigation less the probability of litigation obtained from a probit model based solely on the market variables. By definition, this component of firms' total litigation risk is orthogonal to the market variables, and thus provides a conservative measure of the probability that a firm 
Table 2. Descriptive statistics of litigation experience and litigation risk characteristics.

\begin{tabular}{|c|c|c|c|c|c|}
\hline Variable & Mean & Std. Dev. & Median & Minimum & Maximum \\
\hline Litigation & 0.27 & 0.44 & 0.00 & 0.00 & 1.00 \\
\hline \multicolumn{6}{|c|}{ Characteristics of Frivolous Lawsuits: } \\
\hline MVE & 1.71 & 7.17 & 0.12 & 0.01 & 80.64 \\
\hline Beta & 1.24 & 0.94 & 1.21 & 0.10 & 3.85 \\
\hline Cum. Return & 0.61 & 0.70 & 0.53 & -1.00 & 4.94 \\
\hline Min. Return & -0.28 & 0.13 & -0.26 & -0.89 & -0.06 \\
\hline Skewness & 0.56 & 1.13 & 0.50 & -5.36 & 7.81 \\
\hline Turnover & 0.60 & 0.25 & 0.61 & 0.04 & 1.00 \\
\hline \multicolumn{6}{|c|}{ Characteristics of Meritorious Lawsuits: } \\
\hline$\%$ Independent & 72.03 & 15.17 & 75.00 & 0.00 & 100.00 \\
\hline$\%$ Outside & 3.79 & 9.26 & 0.78 & 0.00 & 46.34 \\
\hline Audit & 0.98 & 0.15 & 1.00 & 0.00 & 1.00 \\
\hline Big 6 & 0.92 & 0.27 & 1.00 & 0.00 & 1.00 \\
\hline Block & 0.73 & 0.44 & 1.00 & 0.00 & 1.00 \\
\hline $\mathrm{COB}$ & 0.60 & 0.49 & 1.00 & 0.00 & 1.00 \\
\hline Founder & 0.33 & 0.47 & 0.00 & 0.00 & 1.00 \\
\hline \multicolumn{6}{|l|}{ Factors: } \\
\hline CEO Power & -0.00 & 0.99 & -0.13 & -1.70 & 8.95 \\
\hline Monitoring & -0.01 & 1.00 & -0.07 & -1.67 & 1.50 \\
\hline Financing & 0.24 & 0.43 & 0.00 & 0.00 & 1.00 \\
\hline Leverage & 0.38 & 0.27 & 0.33 & 0.03 & 2.35 \\
\hline Insider Sales & 9.87 & 22.12 & 1.32 & -2.42 & 120.41 \\
\hline
\end{tabular}

Litigation = one if the Securities Class Action Alert indicated that the firm was a defendant in a securities class action lawsuit in either 1994 or 1995, zero otherwise, MVE = market value of common equity at the end of the 1994 (billions),

Beta $=$ slope coefficient from a regression of daily returns for the first eleven months of 1995 on the equal-weighted market index,

Cum. Return $=$ cumulative daily return for the first eleven months of 1995 ,

Min. Return $=$ minimum return over any contiguous 20-day trading period during 1994 or the first eleven months of 1995 ,

Skewness = skewness of raw returns, measured using daily returns for the first eleven months of 1995 ,

Turnover $=1-(1-\text { Turn })^{231}$, where Turn is average daily trading volume divided by the number of shares outstanding, and 231 is the number of trading days in the first eleven months of 1995 ,

$\%$ Independent $=$ percentage of directors who are not officers of the company, $\%$ Outside $=$ percentage of outstanding shares held by outside directors,

Audit $=$ one if the firm has an audit committee, zero otherwise,

Big $6=$ one if the firm has a Big 6 auditor, zero otherwise,

Block $=$ one if the firm has an external blockholder who owns at least five percent of the outstanding shares, zero otherwise,

$\mathrm{COB}=$ one if the $\mathrm{CEO}$ is chairman of the board of directors, zero otherwise,

Founder $=$ one if the CEO is the company founder, zero otherwise,

$\mathrm{CEO}$ Power $=\mathrm{a}$ factor obtained from the seven corporate governance variables that is positively correlated with $\mathrm{COB}$ and Founder, 
Table 2. Continued.

Monitoring $=\mathrm{a}$ factor obtained from the seven corporate governance variables that is negatively correlated with Audit, Big 6, and Block,

Financing $=$ one if the firm issued debt or equity in 1994 or 1995, zero otherwise,

Leverage $=$ ratio of debt to equity at the end of 1994 , and

Insider Sales = mean annual net insider sales over the period 1993-95 (millions).

will be sued for committing fraud. The probability that a firm is sued for other factors is the remaining portion of total litigation risk.

We predict that the market's response is decreasing in the incremental probability that the firm will be sued for committing fraud, and increasing in the probability that the firm will be sued for other factors. Distinguishing between frivolous and meritorious litigation is an inherently difficult task (e.g., Avery, 1996; Grundfest and Perino, 1997). However, our model includes an extensive set of merit and non-merit based variables, and thus it is unlikely that our model will misspecify these two components of firms' overall litigation risk. If our proxies do not adequately distinguish between the probability of being subject to a frivolous versus meritorious lawsuit, this will bias against finding evidence of a differential market reaction.

Table 3. Probit analysis of firm characteristics associated with lawsuit filings.

\begin{tabular}{|c|c|c|c|}
\hline Variable & Prediction & Coefficient Estimate & $p$-value \\
\hline Constant & ? & -3.86 & 0.00 \\
\hline MVE & + & 0.03 & 0.00 \\
\hline Beta & + & -0.06 & 0.58 \\
\hline Cum. Return & - & -0.31 & 0.05 \\
\hline Min. Return & - & -6.88 & 0.00 \\
\hline Skewness & - & -0.13 & 0.13 \\
\hline Turnover & + & 1.30 & 0.00 \\
\hline CEO Power & + & 0.28 & 0.02 \\
\hline Monitoring & + & 0.02 & 0.85 \\
\hline Financing & + & 0.43 & 0.08 \\
\hline Leverage & + & 0.43 & 0.21 \\
\hline CEO Power $\times$ Financing & + & -0.14 & 0.52 \\
\hline CEO Power $\times$ Leverage & + & 0.28 & 0.03 \\
\hline Monitoring $\times$ Financing & + & -0.04 & 0.91 \\
\hline Monitoring $\times$ Leverage & + & 0.49 & 0.06 \\
\hline Insider Sales & + & 1.06 & 0.00 \\
\hline Pseudo $\mathrm{R}^{2}$ & 0.41 & & \\
\hline Model $\chi^{2}$ & 201.90 & & \\
\hline
\end{tabular}

The regression variables are defined in Table 2 . 
Table 4. Effect of litigation risk on the stock price reaction to the Private Securities Litigation Reform Act of 1995.

\begin{tabular}{|c|c|c|c|c|c|}
\hline \multirow[b]{2}{*}{ Date } & \multirow[b]{2}{*}{ Event } & \multicolumn{2}{|c|}{ Constant Term Portfolio } & \multicolumn{2}{|c|}{ LITIGATION Portfolio } \\
\hline & & $A R$ & $p$-value ${ }^{\mathrm{a}}$ & $A R$ & $p$-value ${ }^{a}$ \\
\hline $12 / 18 / 95$ & Veto & -0.03 & 0.00 & -0.05 & 0.06 \\
\hline $12 / 20 / 95$ & House Override & 0.02 & 0.02 & 0.07 & 0.01 \\
\hline \multirow[t]{2}{*}{$12 / 22 / 95$} & Senate Override & 0.03 & 0.01 & 0.05 & 0.08 \\
\hline & Cumulative & 0.09 & 0.00 & 0.17 & 0.00 \\
\hline
\end{tabular}

$A R$ is the coefficient estimate $\left(\gamma_{p k}\right)$ of event dummy variables from the following model: $\tilde{R}_{p t}=\alpha_{p}+\beta_{p} \tilde{R}_{m t}+\sum_{k}^{3} \gamma_{p k} D_{k t}+\tilde{e}_{p t}$

where:

$\tilde{R}_{p t}=$ return on portfolio $p$ on each of the 251 trading days in calendar year 1995 , weighted using the Sefcik and Thompson (1986) procedure,

$\tilde{R}_{m t}=$ equal-weighted market return on day $t$, and

$D_{k t}=$ one for the $k$ th event, and zero otherwise.

LITIGATION = estimated litigation probability from the model reported in Table 3.

${ }^{\text {a }}$ Reported $p$-values indicate the one-tailed significance levels of the $t$-statistic (F-

statistic) for the individual (cumulative) reaction.

The results reported in Table 5 are consistent with our predictions. Specifically, the market response to the veto (House and Senate overrides) is positive (negative) for the FRAUD portfolio, indicating that the stock price reaction is decreasing in the incremental probability of being sued for committing fraud. Although the veto and override events are not individually significant, the cumulative impact is significantly negative at the 0.06 level. In stark contrast to these results, the stock price reaction is increasing for the OTHER portfolio, as indicated by the significantly negative (positive) abnormal return to the veto (House and Senate overrides). Moreover, the cumulative abnormal return is significantly positive at the 0.05 level. Taken together, our findings suggest that the PSLRA was less beneficial for firms at greater risk of litigation for fraudulent activity, but that these negative effects were dominated, on average, by the positive wealth effects associated with restricting frivolous securities litigation. ${ }^{15}$

\section{Summary and Concluding Remarks}

This paper examines the impact of the Private Securities Litigation Reform Act of 1995 on shareholder wealth. The PSLRA substantially revises the Securities Act of 1933 and the Securities Exchange Act of 1934, with the intent of protecting public companies and their professional advisors from the costs of frivolous securities litigation. However, its critics argued that it would effectively prevent legitimate claims from being prosecuted, thereby encouraging fraudulent activity. To assess the PSLRA's economic impact on firm value, we examine the market response to the President's unexpected veto and the subsequent Congressional override. Our sample consists of 489 firms from three high-technology industries-pharmaceuticals, computer hardware, and computer 
Table 5. Effect of the components of litigation risk on the stock price reaction to the Private Securities Litigation Reform Act of 1995.

\begin{tabular}{|c|c|c|c|c|c|c|c|}
\hline \multirow[b]{2}{*}{ Date } & \multirow[b]{2}{*}{ Event } & \multicolumn{2}{|c|}{ Constant Term Portfolio } & \multicolumn{2}{|c|}{ FRAUD Portfolio } & \multicolumn{2}{|c|}{ OTHER Portfolio } \\
\hline & & $A R$ & $p$-value ${ }^{\mathrm{a}}$ & $A R$ & $p$-value ${ }^{a}$ & $A R$ & $p$-value ${ }^{\mathrm{a}}$ \\
\hline $12 / 18 / 95$ & Veto & -0.03 & 0.06 & 0.06 & 0.29 & -0.05 & 0.06 \\
\hline $12 / 20 / 95$ & House Override & 0.02 & 0.01 & -0.04 & 0.41 & 0.07 & 0.01 \\
\hline $12 / 22 / 95$ & Senate Override & 0.03 & 0.08 & -0.09 & 0.15 & 0.05 & 0.05 \\
\hline & Cumulative & 0.09 & 0.00 & -0.19 & 0.06 & 0.17 & 0.05 \\
\hline
\end{tabular}

$A R$ is the coefficient estimate $\left(\gamma_{p k}\right)$ of event dummy variables from the following model

$\tilde{R}_{p t}=\alpha_{p}+\beta_{p} \tilde{R}_{m t}+\sum_{k}^{3} \gamma_{p k} D_{k t}+\tilde{e}_{p t}$

where:

$\tilde{R}_{p t}=$ return on portfolio p on each of the 251 trading days in calendar year 1995, weighted using the Sefcik and Thompson (1986) procedure,

$\tilde{R}_{m t}=$ equal-weighted market return on day $t$, and

$D_{k t}=$ one for the $k$ th event, and zero otherwise.

$F R A U D=$ estimated litigation probability from the model reported in Table 3, less the estimated litigation probability obtained from estimation of a probit model excluding the proxies for meritorious litigation, i.e., CEO Power, Monitoring, Financing, Leverage, the interactions among these terms, and Insider Sales. $O T H E R=$ estimated litigation probability from the model reported in Table 3 less FRAUD.

a Reported $p$-values indicate the one-tailed significance levels of the $t$-statistic (F-statistic) for the individual (cumulative) reaction.

software - that are more likely to be affected by litigation reform than firms in the general population.

We find that the PSLRA had a positive impact on equity values, on average, in each of the three industries studied. Moreover, the market response is positively correlated with the probability that a firm will be sued in a securities class action, which we estimate using a broad set of market-based and financial reporting variables. This overall positive reaction, however, masks an important offsetting effect. Specifically, we find that the market reaction is negatively correlated with the incremental probability that a firm will be the subject of a meritorious lawsuit. We interpret these results as evidence that the PSLRA has improved the balance between investor protection and the deterrence of frivolous lawsuits, but that there is still an important role for securities class actions in situations where other mechanisms for curbing fraud are inadequate.

\section{Acknowledgments}

We appreciate the helpful comments of Connie Bagley, Linda Bamber, Michael Bamber, Mary Barth, Bill Beaver, Chris Jones, Ed Maydew, Maureen McNichols, Mort Pincus, Roberta Romano, Catherine Schrand, Doug Skinner, seminar participants at the University of Georgia, the University of Iowa, and Stanford University, and especially Charles Lee (the Editor) and two anonymous reviewers. We thank Nejat Seyhun for the insider trading data. Marilyn Johnson acknowledges the support of Ernst \& Young. Ron Kasznik and Karen 
Nelson acknowledge the support of the Financial Research Initiative at Stanford University Graduate School of Business.

\section{Notes}

1. Although the terms "frivolous" and "meritorious" were frequently used in the litigation reform debate, the primary issue was the treatment of cases that fall somewhere between these two extremes (Avery, 1996). In particular, proponents of the PSLRA were concerned with marginal or speculative cases that, regardless of their merits, are disproportionately costly compared to the likely harm suffered by investors. For ease of exposition, we use the terms frivolous and meritorious to distinguish between cases with relatively little merit and those where fraudulent activity is more likely.

2. For example, see Lampf, Pleva, Lipkind, Prupis \& Petigrow v. Gilbertson, 501 U.S. 350, 376 (1991) (Kennedy, J., dissenting).

3. For example, see "The Class-Action Shakedown Racket" (The Wall Street Journal, September 10, 1991); "Lawsuits Often Follow When Small Firms Go Public" (The Wall Street Journal, January 13, 1992); and "A Frivolous Securities Suit Claims Another Victim: Me" (The Wall Street Journal, September 15, 1993). However, several participants in the reform debate questioned the extent and severity of the alleged litigation crisis. For example, Arthur Levitt, then Chairman of the SEC, argued that it was "difficult to measure how prevalent strike suits are, or even to determine whether the problem is any more serious today than it was ten or twenty years ago" (Avery, 1996, p. 340).

4. Some legal scholars argued that the PSLRA would have no immediate effect on investors because the wording of the legislation is so ambiguous that its wealth implications would not be known until there were clarifying court interpretations and/or SEC administrative actions (Coffee, 1996). Similarly, Schneider and Dubow (1996) argue that there would be no measurable impact on firm value because the PSLRA did not preclude remedy under existing state laws, and would not be successful in motivating managers to increase voluntary disclosure. Johnson, Kasznik, and Nelson (2000) examine the PSLRA's impact on voluntary disclosure of forward-looking information.

5. For ease of exposition, in the remainder of the paper we discuss the overall market reaction to the PSLRA without making explicit reference to the opposite effects that are expected for the veto and House/Senate overrides.

6. These predictions assume that investors are able to distinguish between firms that are likely to be the subject of a frivolous lawsuit and those that are likely to be sued for meritorious reasons, and that our model of litigation risk captures these effects.

7. Similarly, an editorial in The Washington Times indicated that "word has it that Mr. Clinton is reaching for the veto pen" (The Washington Times, 1995).

8. The original vote in the Senate was $65-30$, whereas 66 votes were needed to override the Presidential veto.

9. We also examined the market reaction to 21 events that preceded the Presidential veto, including the introduction of the PSLRA in the House and Senate, committee hearings, floor debates, and recorded votes. Not surprisingly, the untabulated results of this analysis indicate that the market reaction to these events generally was insignificant.

10. Untabulated sensitivity analyses indicate that the market reaction on December 19, 1995 was insignificant. For ease of exposition, the remainder of the paper refers to December 18, 1995 as the date of the Presidential veto.

11. Because we predict that the market would respond in opposite directions for the veto and the House/Senate overrides, the cumulative impact is equal to the negative of the abnormal return to the veto plus the abnormal return on the two override events.

12. Consistent with Dechow, Sloan, and Sweeney (1996), we derive CEO Power and Monitoring from a factor analysis of seven fundamental corporate governance variables: the proportion of insiders on the Board of Directors (\% Independent), the proportion of common shares held by outside directors (\% Outside), the presence of an audit committee (Audit), the use of a Big Six auditor (Big 6), the presence of an external blockholder who owns at least five percent of outstanding shares (Block), the presence of a CEO who is also Chairman of the Board of Directors $(C O B)$, and the presence of a CEO who is also the founder of the company (Founder). Despite differences in the two samples, the results of our factor analysis are similar to those reported in Dechow, Sloan, and Sweeney (1996). Specifically, the first factor, CEO Power, is positively 
correlated with $C O B$ and Founder. The second factor, Monitoring, is negatively correlated with Audit, Big 6, and Block. The cumulative variation explained by the two factors is 44 percent, with approximately 25 percent explained by $C E O$ Power and 19 percent by Monitoring.

13. Although we interpret Leverage as a proxy for firms' incentives to report aggressively, consistent with Dechow, Sloan, and Sweeney (1996), this variable may be an additional proxy for firm risk. However, we believe that our interpretation is more plausible given that this variable is significant only when interacted with the corporate governance proxies. Untabulated results indicate that none of our inferences are altered when we exclude Leverage from our model of litigation risk.

14. One advantage of constructing our litigation risk proxy is that we only need to examine the sign and statistical significance of the abnormal returns for a single portfolio to investigate the effect of litigation risk on the market reaction. An alternative approach would be to form separate portfolios for each of the 15 explanatory variables in Table 3, and then examine each portfolio for evidence of a significant market reaction. The weakness of this approach is that it does not incorporate any of the information gained from our probit analysis of lawsuit filings, and accordingly provides a weaker test of our predictions.

15. The results of an industry level analysis (not tabulated) are similar to those reported in Tables 4 and 5, although generally less significant.

\section{References}

Alexander, J. C. (1991). "Do the Merits Matter? A Study of Settlements in Securities Class Actions." Stanford Law Review 43, 497-598.

American Institute of Certified Public Accountants Committee of Sponsoring Organizations for the Treadway Commission. (1992). Internal Control-Integrated Framework. New York, NY: American Institute of Certified Public Accountants.

American Institute of Certified Public Accountants Special Committee on Financial Reporting. (1994). Improving Business Reporting-A Customer Focus: Meeting the Needs of Investors and Creditors. New York, NY: American Institute of Certified Public Accountants.

Amihud, Y., and H. Mendelson. (1986). "Asset Pricing and the Bid-Ask Spread.” Journal of Financial Economics 17, 223-249.

Avery, J. (1996). "Securities Litigation Reform: The Long and Winding Road to the Private Securities Litigation Reform Act of 1995." Business Lawyer 51, 335-378.

Beneish, M. (1999). "Incentives and Penalties Related to Earnings Overstatements that Violate GAAP." The Accounting Review 74, 425-457.

Bonner, S., Z. Palmrose, and S. Young. (1998). "Fraud Type and Auditor Litigation: An Analysis of SEC Accounting and Auditing Enforcement Releases." The Accounting Review 73, 503-532.

Botosan, C. (1997). "Disclosure Level and the Cost of Equity Capital." The Accounting Review 72, 323-349.

Campbell, J., A. Lo, and A. C. MacKinley. (1997). The Econometrics of Financial Markets. Princeton, NJ: Princeton University Press.

Coffee, J. (1985). “The Unfaithful Champion: The Plaintiff as Monitor in Shareholder Litigation." Law and Contemporary Problems 48, 5-81.

Coffee, J. (1996). "The Future of the Private Securities Litigation Reform Act: or, Why the Fat Lady Has Not Yet Sung." Business Lawyer 51, 975-1007.

Conference Report, Private Securities Litigation Reform Act of 1995, H.R. Rep. No. 369, 104th Cong., 1st Sess., 141 Cong. Rec. H13699 (November 28, 1995).

Dechow, P., R. Sloan, and A. Sweeney. (1996). "Causes and Consequences of Earnings Manipulation: An Analysis of Firms Subject to Enforcement Actions by the SEC." Contemporary Accounting Research 13, 1-36. Easterbrook, F., and D. Fischel. (1985). “Optimal Damages in Securities Cases." University of Chicago Law Review 52, 611-652.

Francis, J., D. Philbrick, and K. Schipper. (1994). "Determinants and Outcomes in Class Action Securities Litigation.” Working paper, University of Chicago.

Grundfest, J., and M. Perino. (1997). "Securities Litigation Reform: The First Year's Experience." Working paper, Stanford University.

Johnson, M., R. Kasznik, and K. Nelson. (2000). "The Impact of Securities Litigation Reform on the Disclosure of Forward-Looking Information by High Technology Firms.” Journal of Accounting Research, forthcoming. 
Jones, C., and S. Weingram. (1996). “The Determinants of 10b-5 Litigation Risk.” Working paper, Stanford University.

Kasznik, R., and B. Lev. (1995). "To Warn or Not to Warn: Management Disclosures in the Face of an Earnings Surprise." The Accounting Review 70, 113-134.

Lang, M., and R. Lundholm. (1996). "Corporate Disclosure Policy and Analyst Behavior." The Accounting Review 71, 467-492.

Levitt, A. (1998). "The Numbers Game.” Remarks delivered at the NYU Conference for Law and Business.

Lys, T., and R. Watts. (1994). "Lawsuits Against Auditors." Journal of Accounting Research 32, 65-93.

National Association of Corporate Directors. (1996). Report of the NACD Blue Ribbon Commission on Director Professionalism. Washington D.C.: National Association of Corporate Directors.

National Journal's Congress Daily. (1995). “Clinton Officially Undecided on Securities Measure.” December 19.

Schipper, K., and R. Thompson. (1983). "The Impact of Merger-Related Regulation on the Shareholders of Acquiring Firms." Journal of Accounting Research 21, 184-221.

Schneider, C., and J. Dubow. (1996). "Forward-Looking Information-Navigating in the Safe Harbor." Business Lawyer 51, 1071-1100.

Sefcik, S., and R. Thompson. (1986). "An Approach to Statistical Inference in Cross-Sectional Models with Security Abnormal Returns as Dependent Variables." Journal of Accounting Research 24, 316-334.

Skinner, D. (1996). "Why is Stockholder Litigation tied to Accounting and Disclosure Problems?" Unpublished manuscript, University of Michigan.

Spiess, D. K., and P. Tkac. (1997). "The Private Securities Litigation Reform Act of 1995: The Stock Market Casts its Vote." Managerial and Decision Economics 18, 545-561.

Summers, S., and J. Sweeney. (1998). "Fraudulently Misstated Financial Statements and Insider Trader: An Empirical Analysis." The Accounting Review 73, 131-146.

The Wall Street Journal. (1995a). "GOP-Controlled House Likely to Limit Investor Suits Against Public Companies.” January 20, C1.

The Wall Street Journal. (1995b). "Clinton Likely to Sign Suit Limits." December 12, A3.

The Wall Street Journal. (1995c). "House Overrides Veto of Bill Curbing Securities Suits, but Senate Fight Looms." December 21, A3.

The Washington Times. (1995). "Dining for Dollars at the White House.” December 19, A20. 